\title{
Reflections
}

\section{Governing a just future: what and how to govern? - commentary to Jones}

\section{PIA BÄCKLUND}

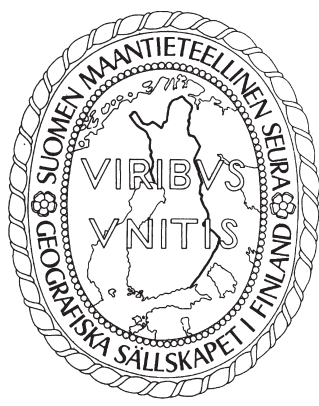

Bäcklund, P. (2019) Governing a just future: what and how to govern? commentary to Jones. Fennia 197(1) 137-140. https://doi.org/10.11143/ fennia.80208

In dealing with the topic of "governing the future", it is fundamental to understand how different practices define justice in content as well as in processual sense. Premises of justification can be seen as essential indicators of the future direction of societal decision-making in governance networks, as well as in determining whose realities play a part when defining future imaginaries. We are dealing with a complex entity and we need to ask whether a future as such can be distinguished from how it is produced in different governing practices? I would also like to emphasize that the concept of 'governance' needs to be taken under careful scrutiny. Governance has not replaced government, as most often both of these management logics are present simultaneously. This is creating tensions within the public sector. My comments to the issues presented in Rhys Jones' article (in this issue) are grounded in planning theory and my ongoing research concerning justification of new spatial planning practices in the Nordic countries.

Keywords: spatial planning, governance, justness, politics of knowing, depoliticization

Pia Bäcklund, Department of Geoscience and Geography, Yliopistonkatu 3, 00014 University of Helsinki, Finland. E-mail: pia.backlund@helsinki.fi

I thank Rhys Jones (2019) for an inspiring text. My comments to the issues presented in the article are grounded generally in planning theory and specifically in my research project Justification for agreementbased approaches in Nordic spatial planning: towards situational direct democracy? (JustDe). JustDe research connects with the themes of regional development and equality. The project investigates, in a Nordic comparative framework, how new agreement-based practices of city-regional strategic spatial planning include and exclude actors and groups, how administrative planning processes define and demarcate what is considered necessary knowledge, and how these practices enable situated political agoras. Through these issues, our aim is to answer the question concerning the ways in which different actors justify the logics of these strategic, territory-spanning planning practices. These justification premises can be seen as essential indicators of the direction societal decision-making in governance networks is taking in the future, and whose realities may play a part in the knowledge practices of planning.

In dealing with the topic of "governing the future", how different practices define justice in content as well as in processual sense is a fundamental issue. For example, agreement-based approaches in spatial planning, while defining actors based on relations, issues and situations, and swiftly crossing administrative territories, utilize seemingly technocratic inclusion and exclusion that, in reality, is 
deeply political. Nevertheless, in the absence of clear legitimacy of such approaches, the actors are forced to justify themselves through indirect attachment to territorially defined representative democracy and institutional administrative structures. I see that this incoherence of action defines the justification of societal decision making in a manner that does not fulfill the preconditions of either representative or direct democracy (see also Bäcklund et al. 2018). This is why it is important to ask what kind of operational governing modes become acceptable in the public sector, and why.

I see that when it comes to governing the future and the spatial justice it produces, we are dealing with a complex entity, where the different parts also interact. Can a future be distinguished as such from how it is produced in different management practices? The future cannot be known, but the future is thought to be based on different things and phenomena that are believed or desired to happen in the future. For example, in planning research the future is seen to be depicted through spatial imaginaries (Davoudi 2018). Spatial imagining always involves the naturalization of certain things, that is, denial of their political nature. In governing the future, there needs to be a starting point, an image, idea or issue, to be anticipated. The ways of governing the future can equally produce the future they are trying to manage, not just react to an already existing one. Urbanization and city-regionalization in general are typical of public administration rhetoric in which things just "happen", and administrative practices must be able to react to them in the future. The question about whose imaginaries of the future are dominant, unwanted or undesirable deals profoundly with spatial and social justice.

Concerning the spatial dimension of governing the future, one of the starting points is that planning is inevitably focused on a limited and defined spatial dimension. Jones' (2019) article pointed out the way in which administrative practices - planning at this point can be thought more broadly as a practice of steering public action - are based on established spatial scales (national, regional, local) and at the same time define what phenomena are central to these scales. An issue that is important at national level is not necessarily noteworthy locally - and vice versa. The latter was presented through a concrete example by Jones: an issue of language, the meaning of which varies locally in individuals' experiential realities.

As we are discussing future governance practices, I would also like to emphasize that the concept of 'governance' in itself does not eliminate the fact that there are still 'governments' that operate according to their own logic in governance networks (see, for example, Mäntysalo \& Bäcklund 2017; Bäcklund et al. 2018). Governance has not replaced government, as both logics are present simultaneously. The tension between governance networks and bureaucratic government in spatial planning can be seen, for example, in the tensioned positioning of public-public partnerships within the state apparatus. According to our research, for instance state-backed agreement-based cityregional planning practices in Finland are conflicting with statutory planning processes and creating gray areas regarding conformance to legislation. Hence, public administration should be accurately conceptualized when dealing with its role in governing or even directing futures: are we talking about one or many actors and rationalities?

There were also good examples of internal government ambivalence in Jones' (2019) article. Particularly interesting were the personal experiences and perceptions of officials concerning the extent to which they have the opportunity to learn to see and do otherwise in their work. I consider such an approach, namely the application of the concept of experiential knowledge to the analytical treatment of public administration, to be of great importance (cf. Bäcklund et al. 2014). The conception of an individual as experiencing her/his environment, as well as of the knowledge concepts that guide individuals and groups in collective decision-making, is strongly linked to the foundation of hermeneutical interpretation and understanding. Thus, I see that action in public administration is a construct of various practices and their interpretations. These interpretations also define the logics of justification of these practices. This field of study is not well portrayed in human geography, yet the thematic is highly relevant, since it combines the issues of how individuals make sense of their world and how societal questions are defined and managed inside public sector activities based on those individual, but intersubjective, interpretations.

I wish to call for more empirical research into different societal contexts and different actors' viewpoints concerning this ambiguity inside public administration. International knowledge transfer has been significant in the appearance of these new practices, yet failures to carefully adapt the new 
practices into new contexts may lead to unintended consequences (Healey 2007; cf. Stead 2012). This is a particularly important point of departure in the Nordic countries, having a self-image of peripherality in European and global contexts. This has prompted accelerated attempts - especially for the metropolitan city-regions - to 'catch up' in the international competition, often with hastily adopted concepts and practices that do not 'ground' into local realities (cf. Smas \& Schmitt 2015).

I see that contemporary spatial planning discussions concretize well the challenges of governing the future from the point of view of justice. Following Deweyan pragmatist thinking that has later been addressed in planning theory by for example John Friedmann, I hold that planning deals with the linkage between knowing and (organized) action. Planning is a mode of governing that always includes/ excludes certain actors and logics of knowledge/knowing - hence also different issues. Our interest in JustDe lies in those processes that define and reproduce the subject matter of planning, and the justifications of the processes. From this starting point, we are studying the new forms of governance and democratic practices as important components of spatial development within the situated public sector constructs that produce spatial and territorial (in)equalities. With the appearance of 'strategically' redistributive planning practices that target localities unevenly and selectively, the democratic underpinnings of planning and public governance are seen to be under threat of erosion in an unprecedented manner (Bäcklund \& Kanninen 2015; Mäntysalo et al. 2015; Bäcklund et al. 2018).

When discussing the content and modes of governing for the future, I like to use the concept "politics of knowing" (Bäcklund 2007) that refers to conceptualizing knowing as an active deed, which means actively making choices about what things are worth knowing - and what the definitions of legitimate knowledge are (Bäcklund et al. 2014). In this respect, the main questions deal with what kind of interpretations of knowledge and knowledge management practices are utilized to justify planning and plans. The tension between the so-called objective knowledge, perceived as factual, and interpretive knowledge impedes the formation of a common understanding concerning what kind of information, in general, is necessary regarding the issue in question (e.g. Davoudi 2012). For example, should the city-regional planning issues be focused on and "technicalised" into economic growth and competitiveness, if the consequence is remarkable narrowing of what is considered appropriate knowledge (see also Swyngedouw 2009; Purcell 2013).

Like many future-oriented activities of envisioning and planning, the agreement-based processes "invite" actors to "ready-made tables," thus leaving the agenda-setting power hidden. The outcomes may be presented as flowing naturally from the premises, not requiring political contemplation. Allmendinger and Haughton (2012) point out that this does not mean conflict has been cast away. It is likely to be just more intricately "choreographed": smokescreened, sidetracked, located elsewhere or marginalized (cf. Beveridge 2012; Kanninen 2018). This means depoliticizing both the form and content of the process. Such action points at a democratic ideal of deliberate, situational selectivity. From its own viewpoint, this sort of democracy is equally catering for the good of the involved "us" as is representative democracy for the good of all "citizens" (Bäcklund et al. 2018; cf. Ranciere 1995).

What is just and democratic in the future? The relevant starting point for the analysis of justice in the future could incorporate the democracy-theoretical and politico-philosophical views of Mouffe (2000), concerning agonistic confrontation as an integral part of societal action. Even if Mouffe's theoretical standpoint has been criticized (e.g. Roskamm 2015), also communicative planning proponents are accepting the agonistic approach as the best fit for planning situations (e.g. Innes \& Booher 2015). Agonistic undertaking of differences also needs a public sphere to enable politicization of issues, which is well portrayed by Jones' (2019) article. Thus, planning conflicts can be seen desirable - not problematic - for the development of democracy (Hillier 2003; Bäcklund \& Mäntysalo 2010; Kanninen et al. 2013) and justness (Fainstein 2018), insofar as they, in the spirit of agonism, create spaces that advance democracy, diversity and equity.

\section{References}

Allmendinger, P. \& Haughton, G. (2012) Postpolitical spatial planning in England: a crisis of consensus? Transactions of the Institute of British Geographers 37(1) 89-103. https://doi. org/10.1111/j.1475-5661.2011.00468.x 
Beveridge, R. (2012) Consultants, depoliticization and arena-shifting in the policy process: privatizing water in Berlin. Policy Sciences 45(1) 47-68. https://doi.org/10.1007/s11077-011-9144-4

Bäcklund, P. (2007) Tietämisen politiikka. Kokemuksellinen tieto kunnan hallinnassa [Politics of knowing. Experiential knowledge in city governance]. Doctoral dissertation. Department of Geography, Faculty of Science, University of Helsinki. http://urn.fi/URN:ISBN:978-952-473-991-7

Bäcklund, P. \& Kanninen, V. (2015) Valtaistetut asukkaat: Neighbourhood Planning ja asuinalueperustaisen osallistumisen rajaamisen taktiikat [Empowered citizens: Neighbourhood Planning and the tactics of demarcating residence-based participation]. Alue \& Ympäristö [Finnish Regional and Environmental studies] 44(1) 4-16.

Bäcklund, P. \& Mäntysalo, R. (2010) Agonism and institutional ambiguity: ideas on democracy and the role of participation in the development of planning theory and practice - the case of Finland. Planning Theory 9(4) 333-350. https://doi.org/10.1177/1473095210373684

Bäcklund, P., Kallio, K. \& Häkli, J. (2014) Residents, customers or citizens? Tracing the idea of youthful participation in the context of administrative reforms in Finnish public administration. Planning Theory \& Practice 15(3) 311-327. https://doi.org/10.1080/14649357.2014.929726

Bäcklund, P., Häikiö, L., Leino, H. \& Kanninen, V. (2018) Bypassing publicity for getting things done: between informal and formal planning practices in Finland. Planning Practice \& Research 33(3) 309-325.

Davoudi, S. (2012) The legacy of positivism and the emergence of interpretive tradition in spatial planning. Regional Studies 46(4) 429-441. https://doi.org/10.1080/00343404.2011.618120

Davoudi, S. (2018) Kaupunkiseudun imaginaari [The city-regional imaginary]. The Finnish Journal of Urban Studies 56(3).

Fainstein, S. (2018) Urban planning and social justice. In Gunder, M., Madanipour, A. \& Watson, V. (eds.) The Routledge Handbook of Planning Theory, 130-142. Routledge, London.

Healey, P. (2007) Urban Complexity and Spatial Strategies: Towards a Relational Planning for Our Times. Routledge, London.

Hillier, J. (2003) Agonizing over consensus: why Habermasian ideals cannot be 'real'. Planning Theory 2(1) 37-59. https://doi.org/10.1177/1473095203002001005

Innes, J. \& Booher, D. (2015) A turning point for planning theory? Overcoming dividing discourses. Planning Theory 14(2) 195-213. https://doi.org/10.1177/1473095213519356

Jones, R. (2019) Governing the future and the search for spatial justice: Wales' Well-being of Future Generations Act. Fennia 197(1) 8-24. https://doi.org/10.11143/fennia.77781

Kanninen, V. (2018) Postpolitics of (Scottish) planning: gatekeepers, gatechecks and gatecrashers? commentary to Walton. Fennia 196(1) 131-134. https://doi.org/10.11143/fennia.69905

Kanninen, V., Bäcklund, P. \& Mäntysalo, R. (2013) Trading zone and the complexity on planning. In Balducci, A. \& Mäntysalo, R. (eds.) Urban Planning as a Trading Zone, 159-178. Springer, Dordrecht. https://doi.org/10.1007/978-94-007-5854-4 10

Mouffe, C. (2000) The Democratic Paradox. Verso, London.

Mäntysalo, R. \& Bäcklund, P. (2017) Flexibly networked, yet institutionally grounded: the governance of planning. In Gunder, M., Manadipour, A. \& Watson, V. (eds.) The Routledge Handbook of Planning Theory, 237-249. Routledge, New York and London.

Mäntysalo, R., Kangasoja, J. K. \& Kanninen, V. (2015) The paradox of strategic planning: a theoretical outline with a view on Finland. Planning Theory \& Practice 16(2) 169-183. https://doi.org/10.1080/ 14649357.2015 .1016548

Purcell, J. (2013) The right to the city: the struggle for democracy in the urban public realm. Policy \& Politics 43(3) 311-327. https://doi.org/10.1332/030557312X655639

Ranciere, J. (1995) On the Shores of Politics. Verso, London.

Roskamm, N. (2015) On the other side of "agonism": "the enemy," the "outside," and the role of antagonism. Planning Theory 14(4) 384-403. https://doi.org/10.1177/1473095214533959

Smas, L. \& Schmitt, P. (2015) Brave new 'megaregional worlds'? Reflections from a North European perspective. In Harrison, J. \& Hoyler, M. (eds.) Megaregions: Globalization s New Urban Form?, 146174. Edgar Elgar, Cheltenham.

Stead, D. (2012). Best practices and policy transfer in spatial planning. Planning Practice \& Research 27(1) 103-116. https://doi.org/10.1080/02697459.2011.644084

Swyngedouw, E. (2009) The antinomies of the postpolitical city: in search of a democratic politics of environmental production. International Journal of Urban and Regional Research 33(3) 601-620. https://doi.org/10.1111/j.1468-2427.2009.00859.x 